\title{
Revitalisasi Konsep Amanat Agung dalam Matius 28:18-20 dan Implementasinya bagi Penginjilan di Masa Pandemi Covid-19
}

\author{
Aldrin Purnomo ${ }^{1 *}$, Arie Agustin ${ }^{2}$, Rima Kurnia ${ }^{3}$, Frederik Patar \\ Hutahaean ${ }^{4}$,Wadison Petrus ${ }^{5}$, Wiwiet Arie Shanty ${ }^{6}$ \\ 1,2, 3, 4, 5, ${ }^{6}$ Mahasiswa Pasca sarjana Prodi Teologi, STT Real Batam \\ septewaruwu@gmail.com
}

\begin{abstract}
The basic concept carried out in the Great Commission is evangelism and discipleship carried out by churches and Christian communities throughout the world, including in Indonesia. This concept is run with a face-to-face pattern and verbally communicate with each other physically. However, all these patterns of activity had to be halted in the midst of the Covid-19 virus outbreak that swept the world. For that we need a strategy by applying new patterns so that the work of evangelism and discipleship can still be carried out. From the results of the analysis conducted through desk research and focus group discussions, it was agreed that the Church must force itself to reposition, seek and find the most appropriate solution to overcome this limitation. The development of digital technology actually has a positive potential for revitalizing the great mandate in evangelism and discipleship programs to be wide open.
\end{abstract}

Keywords: revitalization, great commission, evangelism, theology, covid-19

\begin{abstract}
Abstrak
Konsep dasar yang dilakukan dalam Amanat Agung adalah penginjilan dan pemuridan yang dilakukan oleh gereja maupun komunitas Kristen di seluruh dunia termasuk di Indonesia. Konsep ini dijalankan dengan pola tatap muka dan saling berkomunikasi verbal secara fisik. Namun semua pola kegiatan ini harus mengalami penghentian di tengah wabah virus Covid-19 yang melanda dunia. Untuk itu diperlukan sebuah strategi dengan menerapkan pola-pola baru agar pekerjaan penginjilan dan pemuridan dapat tetap dapat dijalankan. Dari hasil analisis yang dilakukan melalui desk research dan focus group discussion, disepakati bahwa Gereja harus memaksa dirinya untuk melakukan reposisi, mencari dan mendapatkan solusi yang paling tepat untuk mengatasi keterbatasan ini. Berkembangnya teknologi digital justru berpotensi secara positif bagi revitalisasi amanat agung dalam program-program penginjilan dan pemuridan menjadi terbuka lebar.

Kata kunci: revitalisasi, amanat agung, penginjilan, teologi, covid-19Kata
\end{abstract}




\section{PENDAHULUAN}

Amanat Agung dalam Matius 28:18-20 adalah bentuk perwujudan kasih Allah kepada manusia yang nyata dan tidak pernah berubah sampai Tuhan Yesus datang kembali. Bentuk kasih ini adalah refleksi hati Allah setelah manusia jatuh ke dalam dosa (Kej.3:9). Inisiatif yang datang dari Allah sendiri untuk mencari yang terhilang dinyatakan langsung oleh Yesus dalam Markus 16:15 untuk menjadi saksi, mencari yang hilang, menyelamatkan dan membawa yang terhilang kepada Kristus. ${ }^{1}$ Karena misi ini terus berlaku hingga saat ini, maka misi penyelamatan ini adalah sebuah perjalanan spiritual yang harus dilakukan oleh setiap komunitas Kristen dan setiap individu di dalamnya sebagai sentuhan spiritual yang sebenarnya. Perjalanan misi yang melintasi waktu dan tepat yang memancar dalam berbagai konteks kehidupan manusia dalam sejarah dan posisi geografis yang Tuhan telah tetapkan bagi kita. $^{2}$ Di Indonesia perjalanan ini telah melalui berbagai rentang waktu yang sangat panjang dan tantangan yang luar biasa. Program penginjilan di Indonesia sudah dimulai semenjak hadirnya agama Kristen di Indonesia pada abad ke $7 .{ }^{3}$ Hingga saat ini Indonesia tetap menjadi ladang penginjilan yang menjadi tanggung jawab setiap umat Kristiani sebagai bentuk perwujudan perjalanan spiritualnya.

Kehadiran virus Corona di dunia, memberikan pengaruh yang signifikan bagi seluruh kegiatan manusia termasuk kegiatan penginjilan di Indonesia. Virus yang dimulai dari kota Wuhan Cina ini bermutasi dan menyebar dengan cepat ke seluruh dunia dan memaksa suatu kondisi pandemi yang di tetapkan oleh World Health Organization (WHO) semenjak 9 Maret 2020. ${ }^{4}$ Pemerintah Indonesia harus membentuk Gugus tugas penanganan Covid-19 berdasarkan Peraturan Presiden No. 7 tahun 2020 tanggal 13 Maret 2020. Berdasarkan peraturan tersebut, pemerintah daerah di masing-masing provinsi, kabupaten dan kota mengeluarkan serangkaian regulasi untuk menekan laju penularan virus Covid-19. Sederet kebijakan yang diterapkan

\footnotetext{
${ }^{1}$ Fransiskus Irwan Widjaja, Daniel Ginting, and Sabar Manahan Hutagalung, “Teologi Misi Sebagai Teologi Amanat Agung," Thronos 1, no. 1 (2019): 17-24.

${ }^{2}$ Stuart C Bate O M I, "Method in Contextual Missiology 2 . A Method for Reflection as We Walk the Spiritual Journey : Some Presuppositions," no. 1962 (1998): 135.

3 "Kekristenan Di Indonesia," Wikipedia, last modified 2021, accessed April 17, 2021, https://id.wikipedia.org/wiki/Kekristenan_di_Indonesia\#: :text=Agama Kristen pertama kali datang,di Sumatra (645 M).

${ }^{4}$ Satuan Tugas Penanganan COVID-19, "Apa Yang Dimaksud Dengan Pandemi?," last modified 2021, accessed April 16, 2021, https://covid19.go.id/tanya-jawab?search=Apa yang dimaksud dengan pandemi.
} 
adalah pembatasan pergerakan masyarakat, penerapan protokol kesehatan yang ketat dan pengaturan ruang kerja dan kegiatan belajar mengajar dari rumah. Peraturan-peraturan ini bersifat mengikat bagi seluruh kegiatan masyarakat di Indonesia selama pandemi dan memiliki sanksi hukum bagi yang melakukan pelanggaran.

Dua hal yang menjadi kunci pencegahan penyebaran Covid-19 di Indonesia adalah pembatasan pergerakan masyarakat dan penerapan protokol kesehatan. Pembatasan pergerakan masyarakat ditetapkan melalui penerapan peraturan pembatasan kegiatan sosial dan ekonomi oleh seluruh Pemerintah daerah 34 Provinsi di Indonesia. Dampak dari penerapan pembatasan ini mengakibatkan turunnya tren mobilitas masyarakat sesuai data Google Community Mobile Report, yang menunjukkan terjadinya penurunan mobilitas masyarakat pada periode pertengahan Februari hingga Maret 2020 hingga $-26 \%{ }^{5}$

Gambar.1. Tren mobilitas masyarakat Indonesia bulan Februari hingga Maret 2020
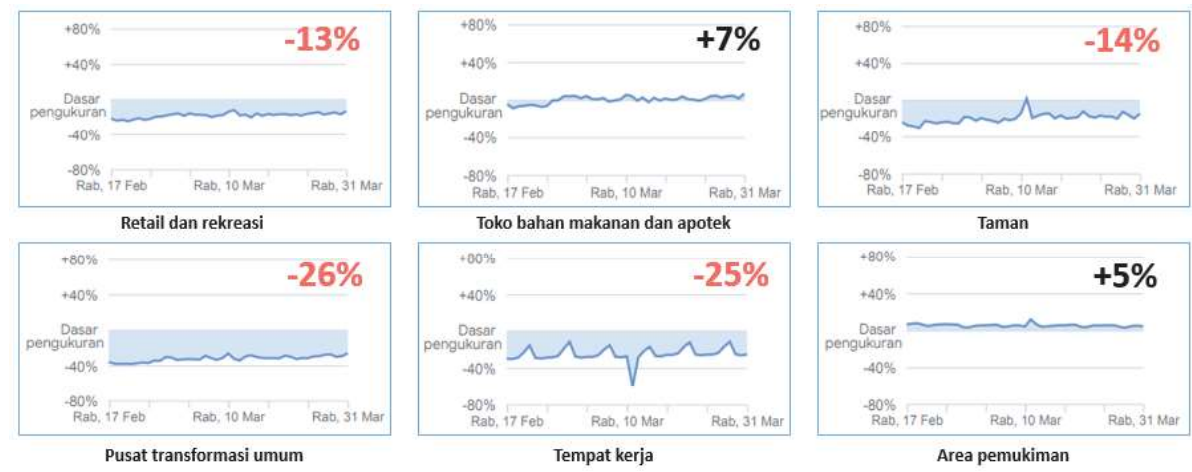

Penerapan standar protokol kesehatan yang ditetapkan telah membatasi jarak pertemuan orang ke orang sebagai langkah preventif pada masa pandemi. ${ }^{6}$ Istilah pengaturan jarak sosial ini mengakibatkan setiap orang tidak bisa lagi bersalaman (bersentuhan), pembatasan jumlah populasi orang dalam sebuah pertemuan dan pemasangan partisi tembus pandang untuk setiap titik yang memerlukan komunikasi fisik secara langsung (face to face meeting), peniadaan ibadah di rumah ibadah, pembatalan perayaan-perayaan, dan pembatalan mudik lebaran. Dari hasil penelitian yang dilakukan oleh Nina

\footnotetext{
${ }^{5}$ Hermawan Saputra and Nadilah Salma, "Dampak PSBB Dan PSBB Transisi Di DKI Jakarta Dalam Pengendalian COVID-19," Media Kesehatan Masyarakat Indonesia 16, no. 3 (2020): 282-292.

${ }^{6}$ KemenKes_RI, “Tata Laksana,” KKBI Daring (2020), https://kbbi.kemdikbud.go.id/entri/Tata Laksana.
} 
Novira et al., terhadap 2.828 responden di seluruh Indonesia, terdapat 87,9 persen responden yang menganggap pembatasann sosial ini sangat penting. Hal ini menunjukkan bahwa masyarakat Indonesia menganggap bahwa pembatasan sosial tersebut penting. ${ }^{7}$

Pembatasan pergerakan masyarakat baik yang diatur di dalam regulasi pemerintah Indonesia maupun di dalam protokol kesehatan, sangat mempengaruhi kegiatan penginjilan yang telah dilakukan selama ini. Pembatasan pergerakan membuat para penginjil atau pekerja misi tidak dapat menemui obyek misinya secara langsung bahkan harus membatalkan semua proyek misi yang telah direncanakan sebelumnya. Pergerakan penginjilan mengalami penghentian akibat kondisi ini. Dalam berbagai wawancara langsung dengan pelaku misi baik dari organisasi Kristen maupun gereja, proyek penginjilan yang terhenti adalah penginjilan ke beberapa daerah yang belum terjamah oleh Injil, pemberian bantuan sosial kepada daerah-daerah terpencil dan pengiriman tim misi ke daerah-daerah tertinggal. Para pelaku misi berpendapat bahwa perlu dilakukan revitalisasi dengan menerapkan polapola baru. Penerapan kondisi kenormalan baru (New Normal) akibat pandemi Covid-19 dianggap sebagai suatu tantangan baru dalam melakukan proses penginjilan. Revitalisasi ini mencakup peninjauan konsep dan implementasi penginjilan di Indonesia berdasarkan kondisi kenormalan baru ini.

Oleh sebab itu penulis setuju dengan pendapat Fransiskus Irwan Widjaja dkk dalam tulisannya sebagai berikut, With the change in the pattern of life, there's a need to re-reflect on the models of mission that have been adhered to consistently. Old habits that have been successful in the past are not necessarily relevant today. Mission needs to be reorganized to answer the needs of this generation, following the challenges of the contemporary era. ${ }^{8}$

\section{METODE}

Penelitian ini merupakan penelitian kualitatif dengan metode studi kepustakaan (desk research), serta melakukan Focus group Discussion. Salah satu metode studi kepustakaan yang digunakan adalah analisis sintesis untuk menemukan perspektif strategi yang baru bagi keberlangsungan proses penginjilan di masa pandemi Covid-19. Menurut Jonathan Sarwono, studi kepustakaan yang dilakukan terhadap kedua hal ini bertujuan untuk

\footnotetext{
${ }^{7}$ Nina Novira, Rudi Iskandar, and Raehanul Bahraen, "Persepsi Masyarakat Akan Pentingnya Social Distancing Dalam Penanganan Wabah Covid-19 Di Indonesia," Jurnal Kependudukan Indonesia 2902 (2020): 27.

${ }^{8}$ Fransiskus Irwan Widjaja, Fredy Simanjuntak, and Noh Ibrahim Boiliu, "Repositioning Mission in Postmodern Culture," in Proceedings of the 1st International Conference on Education, Society, Economy, Humanity and Environment (ICESHE 2019) (Paris, France: Atlantis Press, 2020), https://www.atlantis-press.com/article/125936174.
} 
membandingkan sesuatu yang terjadi saat ini dengan kegiatan yang telah dilakukan di masa lampau sehingga hasilnya mendorong terciptanya sebuah perspektif baru yang bisa diterapkan di masa kini. ${ }^{9}$ Focus group Discussion (FGD) dilakukan untuk melakukan pengolahan data secara bersama-sama untuk mendapatkan analisis yang tepat serta memperdalamnya menuju sebuah kesimpulan. Proses diskusi dan analisis dilakukan sebagai sebuah tahapan FGD yang baik sesuai yang disarankan oleh Hengki Wijaya. ${ }^{10}$ Di dalam FGD dilakukan analisis alternatif metode penginjilan dengan cara digital berdasarkan survei yang dilakukan oleh lembaga yang kredibel di bidang ini. Periode waktu survei yang dipakai lembaga ini berada di rentang terjadinya pandemi Covid-19 di Indonesia. Data dari hasil survei ini dijadikan bahan pertimbangan untuk menentukan pola baru tersebut.

\section{HASIL DAN PEMBAHASAN}

\section{Konsep Amanat Agung}

David J. Bosch menjelaskan bahwa dasar misi di dalam Matius adalah sebuah terobosan dari situasi front Yudaisme Farisi dan kekristenan Yahudi yang helenistik. Dalam hal ini terdapat beberapa konsep teologi misi yang saling terikat satu dengan yang lainnya. Konsep-konsep yang dimaksud adalah Pemerintahan Allah, kehendak Allah, kebenaran, perintah-perintah, tantangan untuk menjadi sempurna, menjadi unggul, memelihara, berbuah dan mengajar. Bagian terakhir dari hal ini adalah mengajar yang tercantum dalam Matius 28:20 "dan ajarlah mereka melakukan segala sesuatu yang telah Kuperintahkan kepadamu", dan di kuatkan dengan frasa perintah "dan baptislah mereka". ${ }^{11}$ Matius sendiri akhirnya melukiskan praktik misionaris yang dilakukan Yesus dan para murid pada jamannya dan berlaku seterusnya dalam konsep: "mengutus", "pergi", "memberitakan", "menyembuhkan", "mengusir roh-roh", "mendamaikan", "bersaksi”, "mengajar", dan "menjadikan murid". Dengan konsep-konsep Matius inilah orang Kristen menemukan identitas sejati mereka apabila mereka terlibat dengan misi, dalam melakukan komunikasi dengan orang lain tentang cara hidup yang baru, penafsiran baru terhadap realitas hidup, pemahaman tentang Allah dan dalam penyerahan diri mereka bagi pembebasan dan keselamatan orang lain. ${ }^{12}$

Konsep yang dilakukan dalam Amanat Agung adalah penginjilan dan pemuridan. Secara etimologis penginjilan adalah sebuah proses yang diartikan

\footnotetext{
${ }^{9}$ Jonathan Sarwono, Metode Penelitian Kuantitatif Dan Kualitiatif (Yogyakarta: Graha Ilmu, 2006), 47-48.

${ }^{10}$ Hengki Wijaya, Analisis Data Kualitatif Ilmu Pendidikan Teologi, Populasi Dan Sampel (Makassar: Sekolah Tinggi Theologia Jaffray, 2018). 82-85

${ }^{11}$ David J. Bosch, Transformasi Misi Kristen (Jakarta: BPK Guniung Mulia, 2016). 101-102.

${ }^{12}$ Ibid.
} 
sebagai: (1) Satu tugas untuk mengumumkan atau memberitakan kabar baik, dan atau kabar keselamatan di dalam Yesus Kristus; (2) Dilakukan dengan cara menyerukannya seperti seorang utusan raja yang sedang mengumumkan satu dekrit, yaitu dengan suara yang keras dan tegas. Pemuridan adalah pengajaran yang didasari tujuan menjadikan pengikut yang setia. Pemuridan merupakan suatu proses pelipatgandaan secara dinamis yang dapat menjangkau orang yang telah mengerti akan pengajaran tentang Kristus baik itu anak, remaja sebagai generasi penerus. Tujuan akhir dari konsep ini adalah menjadikan manusia serupa dengan Allah (2 Korintus 3:18) sehingga kita diubah menjadi segambar dengan-Nya, dalam kemuliaan yang semakin besar (1 Yohanes 3:2). ${ }^{13}$

\section{Gereja dan umat yang misioner}

Dalam konteks penginjilan di dalam Perjanjian baru, gereja mengambil peran yang sangat penting untuk melakukan penginjilan dan pemuridan ini. Konsep Gereja Misioner harus dilaksanakan oleh setiap gereja sebagai bentuk panggilannya di dalam dunia. Walaupun demikian, penginjilan dan pemuridan harus dipahami dengan sebuah paradigma yang tepat. Yang memerintahkannya adalah Allah sendiri dan manusia sebagai pelaku misi. Paradigma ini diperkuat oleh Konferensi Edinburg pada tahun 1910 yang menyatakan bahwa misi tersebut berfokus kepada tugas panggilan umat Kristen dengan semua strategi, sumber daya insani, dana dan lain-lain yang diperlukan untuk menunaikan tugas ini. ${ }^{14}$ Dietrich Bonhoeffer menulis bahwa Gereja adalah gereja saat ia hidup untuk orang lain. Konferensi Willingen menyatakan bahwa partisipasi umat Kristen di dalam Kristus dinyatakan melalui partisipasinya di dalam misi kepada dunia. Paradigma missio Dei ini menjadi pegangan baik seluruh denominasi dan komunitas Kristen di seluruh dunia. $^{15}$

Dalam konteks pelaksanaan misi di Indonesia, Irwan Widjaya membagi sasaran Gereja Misioner dalam empat arah misi yang dijalankan yaitu: (1) Misi reguler, yang merupakan bagian dari misi denominasional; (2) Misi suku terabaikan, yang merupakan pelayanan misi bagi suku-suku yang berada di sekitar domisili kita; (3) Misi suku terasing, yaitu pelayanan misi

\footnotetext{
${ }^{13}$ Novita, "Pemuridan: Jalan Menuju Kedewasaan Penuh Dalam Kristus," In-Christ, last modified 2008, accessed April 17, 2021, https://www.in-

christ.net/artikel/misi/pemuridan_jalan_menuju_kedewasaan_penuh_dalam_kristus.

${ }^{14}$ John Ruck et al, Jemaat Misioner (Jakarta: Yayasan Komunikasi Bina Kasih, 2011). 33

${ }^{15}$ Ibid. 35 .
} 
bagi suku-suku terasing, terbelakang dan jauh dari peradaban manusia; (4) Misi memperkuat kantong-kantong Kristen, yang bertujuan memperkuat keimanan anak-anak Tuhan di daerah Kristen yang mulai dimasuki oleh kaum Kedar. ${ }^{16}$ Konteks geografi misi inilah yang menjadikan peta tujuan misi harus dilaksanakan dengan efisien dan efektif sesuai dengan konteks budaya Indonesia. ${ }^{17}$

\section{Revitalisasi Konsep Amanat Agung}

Globalisasi dan perubahan teknologi yang sangat cepat di bidang informasi dengan berbagai bentuk produk teknologi komunikasi digital membentuk sebuah tatanan komunikasi baru dengan cakupan global. Di dalam pergeseran dari masyarakat yang tradisional ke masyarakat cerdas di era digital, digitalisasi mengambil peranan yang penting dengan semua dimensi yang ditawarkannya. Keterbukaan interaksi sesama manusia membentuk pola sosial, antropologi, mental dan spiritual manusia. Agama yang selalu hadir di dalam setiap pergeseran ini telah difasilitasi oleh teknologi sehingga teknologi turut memberikan kontribusi terhadap seluruh konteks teologi. Teologi sendiri telah berpengaruh terhadap dunia maya yang meluas kepada kegiatan politik, bisnis dan kehidupan sosial. Digitalisasi semakin hari semakin terhubung dengan teologi secara kontekstual yang berpengaruh kepada struktur berpikir, kontribusi ke dalam dunia pendidikan, merangsang kecerdasan dan membuka pemikiran baru teologi. Sehingga terjadi hubungan mutualisme antara digital dan teologi sebagai bentuk pengaruh bersama di era digital yang memaksa teologi untuk dekontekstualisasi dan digitalisasi yang mengakomodasi teologi. ${ }^{18}$ Dalam konteks inilah, teologi misi juga turut berubah mengikuti bentuk pergeseran dari sisi tradisional ke arah sisi cerdas dalam era digital yang baru.

Perkembangan teknologi turut mempengaruhi gereja di dalam melaksanakan revitalisasi penginjilan dan pemuridan sebagai bentuk implementasi dari Amanat Agung. Untuk itu gereja perlu melakukan semacam reposisi pemikiran kepada setiap anak Tuhan melaksanakan program penginjilan dan pemuridan di era digital ini. ${ }^{19}$ Kemajuan teknologi digitalisasi

${ }^{16}$ Fransiskus Irwan Widjaja, Misiologi Antara Teori Fakta Dan Pengalaman (Yogyakarta: Penerbit Andi, 2018), 64-68.

17 John Ruck et al, Jemaat Misioner. 49.

${ }^{18}$ Christar Arstilo Rumbay, "Christology in Digital Era: A Socio-Systematic Theology Contribution to the Sustainable Smart Society," PASCA : Jurnal Teologi dan Pendidikan Agama Kristen 16, no. 1 (2020): 15-23.

${ }^{19}$ Kevin Tonny Rey, "Konstruksi Teologi Dalam Konteks Reposisi Pemikiran Warga Gereja," EPIGRAPHE: Jurnal Teologi dan Pelayanan Kristiani 2, no. 1 (2018). 
harus dipahami telah mengubah banyak aspek hidup manusia, dan tanpa mengabaikan indikator kegiatan dalam melaksanakan Amanat Agung. Sehingga penginjilan dan pemuridan membuat jarak semakin dekat dan semakin mudah untuk di kunjungi. Melalui akses internet kita dapat hadir di tempat dan wilayah di seluruh nusantara bahkan dunia. Sehingga gereja lebih fleksibel dan dapat menjawab kebutuhan penginjilan dalam situasi sulit sekalipun. Dengan mempertahankan konsep penginjilan sebagai sebuah landasan bagi iman Kristiani yang sangat berguna untuk membangun hubungan dengan orang-orang dan berbagi semangat dengan cara yang bijaksana dan menyenangkan sebagai Juru Selamat serta menjadi murid yang rela menyangkal diri, memikul salib, dan melayani Dia.

Menurut Jonas Kulberg, telah terjadi revolusi digital di dunia misi. Gereja telah melakukan intervensi untuk menggunakan sarana internet dan digital di dalam dunia pelayanan. Salah satunya adalah Church of England yang telah melakukan program misi dengan sarana digital sejak tahun 2016. Contoh yang lain adalah gereja Metodis di Inggris yang mempekerjakan pegawai khusus yang menangani pelayanan misi melalui dunia digital yang bukan hanya memproduksi konten-konten misi tetapi juga kursus-kursus teologi dari berbagai institusi pendidikan. ${ }^{20}$ Covid-19 memaksa gereja melakukan perpindahan pelayanan menggunakan teknologi komunikasi digital. Terjadi lonjakan penggunaan internet dan komunikasi data yang dilakukan oleh gereja. Hal ini juga memberikan peningkatan jumlah orang yang hadir terutama bagi mereka yang biasanya tidak pernah hadir di gereja. ${ }^{21}$ Menemukan Yesus secara daring adalah sebuah strategi yang harus dikerjakan oleh gereja dan para penginjil. Dunia pos-modernisme dengan transformasi digital di dalamnya, memaksa gereja untuk melakukan strategi yang berbeda dengan segera. Batas yang kabur antara dunia realitas dan virtual mengundang konsepsi yang berbeda terhadap dunia teologis yang jauh lebih luas. Melalui platform media digital, setiap institusi keagamaan telah menemukan platform yang bisa menjangkau setiap orang secara langsung. ${ }^{22}$

\section{Digitalisasi sebagai solusi}

Pandemi Covid-19 memaksa gereja melakukan perubahan strategi dalam melakukan penginjilan dan pemuridan. Untuk membangkitkan kembali

\footnotetext{
${ }^{20}$ Jonas Kurlberg, "Introduction: Missio Dei in a Digital Age," in Missio Dei in a Digital Age, ed. Jonas Kurlberg and Peter M. Phillips (London: SCM Press, 2020). 13.

${ }^{21}$ Ibid.

${ }^{22}$ Jonas Kurlberg, "Doing God in Digital Culture: How Digitality Is Shaping Theology," Cursor_Zeitschrift für explorative Theologie (2020).
} 
proyek-proyek penginjilan dan pemuridan yang sempat vakum akibat pembatasan Covid-19, diperlukan strategi revitalisasi untuk menggerakkan kembali kegiatan ini. Istilah revitalisasi sendiri adalah sebuah proses, cara, atau perbuatan menghidupkan dan menggiatkan kembali kegiatan yang sebelumnya pernah ada namun terhenti. ${ }^{23}$ Pemanfaatan teknologi digital adalah cara yang sangat tepat di dalam mengakomodasi tantangan terhentinya program penginjilan dan pemuridan di masa pandemi Covid-19.

Penggunaan internet di Indonesia yang semakin meningkat menunjukkan pola penyampaian informasi yang berbeda dibandingkan dengan pola bertatap muka secara langsung. Hasil survei yang dilakukan oleh Indonesia Survei Center untuk Asosiasi Penyelenggara Jasa Internet Indonesia tahun 2019 - 2020 kuartal kedua menunjukkan beberapa hal yang harus menjadi pertimbangan transformasi pola penginjilan di Indonesia. Berikut adalah beberapa data survei penting yang telah dilakukan oleh Indonesia Survey Center. Total sampel survei ini sebesar 7000 responden dengan margin of error $\pm 1,27$ persen dan persentase hasil survei ada pada rentang $\pm 1,27$ persen. ${ }^{24}$ Data survei yang ditampilkan adalah data survei yang berhubungan dengan potensi melakukan penginjilan lewat secara digital.

Tabel.1. Data survei Penggunaan Internet di Indonesia 2019-2020 Q2

\begin{tabular}{|c|c|c|c|}
\hline \multicolumn{4}{|c|}{$\begin{array}{l}\text { Survei Penggunaan Internet di Indonesia } \\
\text { Tahun } 2019-2020 \text { Q2 }\end{array}$} \\
\hline Penetrasi Internet 2019 & $73,30 \%$ & Pola berlangganan Internet & $79,1 \%$ secara bulanan \\
\hline Pengguna Internet di Indonesia & 196,7 Juta & $\begin{array}{l}\text { Konten internet yang sering } \\
\text { dikunjungi }\end{array}$ & $49,3 \%$ menonton video online \\
\hline Pertumbuhan penetrasi Internet & $8,90 \%$ & Media sosial yang sering dikunjungi & \begin{tabular}{|c|} 
Facebook $(65,8 \%)$, Instagram \\
$(42,3 \%)$ dan Youtube $(61 \%)$
\end{tabular} \\
\hline $\begin{array}{l}\text { Frekuensi terhubung dengan } \\
\text { Internet }\end{array}$ & $95,4 \%$ terhubung setiap hari & $\begin{array}{l}3 \text { Konten Youtube yang sering } \\
\text { ditonton }\end{array}$ & $\begin{array}{c}16,2 \% \text { film; } 13,6 \% \text { musik; } \\
8,9 \% \text { olahraga }\end{array}$ \\
\hline $\begin{array}{l}\text { Rata-rata waktu terhubung } \\
\text { dengan internet per hari }\end{array}$ & $\begin{array}{c}19,5 \% \text { terhubung selama } 8 \\
\text { jam ke atas }\end{array}$ & Konten ceramah agama & $5,3 \%$ \\
\hline $\begin{array}{l}\text { Kualitas sinyal di tempat } \\
\text { melakukan koneksi }\end{array}$ & $\begin{array}{l}71,8 \% \text { sinyal dalam kondisi } \\
\text { baik }\end{array}$ & Konten Pendidikan yang sering dikuju & \begin{tabular}{|l|}
$13,1 \%$ website sekolah; $7,3 \%$ \\
blog keagamaan; $7,3 \%$ website \\
universitas
\end{tabular} \\
\hline \begin{tabular}{|l|} 
Tingkat kepercayaan terhadap \\
keamanan berinternet
\end{tabular} & $57,8 \%$ menyatakan aman & Media komunikasi yang sering diguna & $\begin{array}{l}91,1 \% \text { menggunakan } \\
\text { Whatsapp }\end{array}$ \\
\hline $\begin{array}{l}\text { Alasan utama menggunakan } \\
\text { internet }\end{array}$ & $\begin{array}{c}51,5 \% \text { untuk Sosial Media } \\
32,9 \% \text { untuk komunikasi lewat } \\
\text { pesan }\end{array}$ & Aplikasi video call yang sering digunal & $\begin{array}{l}93,7 \% \text { menggunakan } \\
\text { whatsapp }\end{array}$ \\
\hline
\end{tabular}

bagaimana pola penginjilan bisa dilakukan dengan cara digital yang efektif dan efisien. Menurut Hengki Wijaya, hasil survei seperti penggunaan internet

23 "Revitalisasi," Wikipedia, last modified 2020, accessed April 16, 2021, https://id.wikipedia.org/wiki/Revitalisasi.

${ }^{24}$ Indonesia Survey Center, Laporan Survei Internet APJII 2019 - 2020 (Q2), 2020. 
ini dapat diolah untuk menjadi bahan pertimbangan dalam diskusi mencari strategi yang tepat menuju revitalisasi penginjilan oleh tim karena hasilnya mencakup are yang diteliti, dimensi-dimensi survei yang detail, dan item survei yang baik. ${ }^{25}$

\section{Digitalisasi dalam penginjilan}

Di masa Pandemi Covid-19, kita dituntut untuk beradaptasi dengan suasana dan kebiasaan baru. Agar dapat menjalankan penginjilan dimasa covid-19 beberapa strategi dalam mengkomunikasikan pesan Injil yang dapat dilakukan guna menggiatkan pelayanan penginjilan yang efisien dan efektif ,serta aman di masa pandemi covid-19 melalui metode media digital antara lain melalui khotbah live streaming, rekaman video, Facebook, Instagram, Zoom) dan tatap muka. Pelayanan media sangat berguna untuk menjangkau setiap masyarakat yang sulit untuk dijangkau. Kemajuan bidang teknologi informasi media digital sangat besar pengaruhnya dalam menghadapi situasi pandemi covid -19 , di mana kegiatan ibadah dan penginjilan tidak bisa dijalankan seperti biasa. Media digital membawa model dan gaya baru dalam penginjilan dan berdakwah. ${ }^{26}$ Melalui peran media digital Gereja mampu melayani jemaat dengan tidak terbatas dengan ruang dan waktu dan memberi peluang kepada gereja untuk melakukan penjangkauan jiwa di mana pun mereka berada. Untuk itu Gereja perlu menggunakan media digital untuk menjangkau jiwa jiwa sehingga melalui media digital pemberitaan Injil dapat sampaikan ke seluruh pelosok .

Penginjilan melalui media digital banyak digunakan oleh masyarakat masa kini. ${ }^{27}$ Menurut dosen Fakultas Teologi Universitas Sanata Dharma Bagus Laksana (2020), di masa normal baru, internet menjadi bagian yang signifikan dari cara beragama dan menggereja. Aplikasi - aplikasi seperti Facebook, Instagram, Youtube adalah aplikasi yang sangat terkenal di seluruh masyarakat. Khotbah live streaming merupakan strategi komunikasi dalam penginjilan dengan tambahan alat-alat seperti kamera, mikrofon serta laptop sebagai media perantara dan merekam materi kotbah yang disampaikan. ${ }^{28}$

\footnotetext{
${ }^{25}$ Wijaya, Analisis Data Kualitatif Ilmu Pendidikan Teologi.

${ }^{26}$ Yosua Feliciano Camerling, Mershy Ch. Lauled, and Sarah Citra Eunike, "Gereja Bermisi Melalui Media Digital Di Era Revolusi Industri 4.0," Visio Dei: Jurnal Teologi Kristen 2, no. 1 (2020): 1-22.

${ }^{27}$ Yohanes Widodo, "Media Digital Dan Agama Di Masa Pandemi," Media Indonesia, last modified 2020, accessed April 17, 2021, https://mediaindonesia.com/opini/332670/media-digital-dan-agama-di-masa-pandemi.

${ }^{28}$ Camerling, Lauled, and Eunike, "Gereja Bermisi Melalui Media Digital Di Era Revolusi Industri 4.0."
} 
Bagi masyarakat yang berada jauh dari kota (pedalaman) metari-materi khotbah ini adalah solusi yang tepat dengan mengirimkan rekaman-rekaman tersebut dalam bentuk media data elektronik seperti data suara maupun data video. Data-data yang dimasukkan dalam sebuah dapat disimpan dalam peranti telepon genggam maupun komputer jinjing (laptop).

Tabel.2. Solusi penginjilan dan pemuridan menggunakan sarana digital

\begin{tabular}{|l|l|}
\hline $\begin{array}{c}\text { Tipe kegiatan Penginjilan yang } \\
\text { biasanya (berdasarkan } \\
\text { pengalaman pribadi) }\end{array}$ & $\begin{array}{c}\text { Revitalisasi penginjilan dan pemuridan } \\
\text { dengan digital }\end{array}$ \\
\hline $\begin{array}{l}\text { Kotbah langsung ke jemaat secara } \\
\text { tatap muka }\end{array}$ & Kotbah dengan metode Live Streaming \\
\hline $\begin{array}{l}\text { Penginjilan langsung secara tatap } \\
\text { muka secara pribadi }\end{array}$ & $\begin{array}{l}\text { Pengiriman konten-konten digital melalui } \\
\text { WhatsApp }\end{array}$ \\
\hline $\begin{array}{l}\text { Penginjilan di muka umum } \\
\text { Penginjilan Melakukan KKR } \\
\text { Tentang Keselamatan }\end{array}$ & $\begin{array}{l}\text { Pemuatan konten-konten penginjilan lewat } \\
\text { Facebook, Instagram }\end{array}$ \\
\hline $\begin{array}{l}\text { Melakukan Lawatan } \\
\text { KKR live streaming di FB dan Youtube }\end{array}$ \\
\hline Memberikan layanan sosial & $\begin{array}{l}\text { Menggunakan fasilitas video call di } \\
\text { WhatsApp, Instagram atau Line }\end{array}$ \\
\hline $\begin{array}{l}\text { Kegiatan pemuridan dengan } \\
\text { modul-modul dan tatap muka }\end{array}$ & $\begin{array}{l}\text { Menggunakan fasilitas video call di } \\
\text { WhatsApp, Instagram atau Line }\end{array}$ \\
\hline $\begin{array}{l}\text { Seminar Pembinaan Iman Kristen } \\
\text { muda mudi }\end{array}$ & $\begin{array}{l}\text { Menyelenggarakan kelas zoom untuk } \\
\text { pembimbingan muda mudi }\end{array}$ \\
\hline $\begin{array}{l}\text { Memberikan kesaksian akan } \\
\text { kebaikan Tuhan }\end{array}$ & $\begin{array}{l}\text { Menggunakan fasilitas video call di } \\
\text { WhatsApp, Instagram atau Line }\end{array}$ \\
\hline $\begin{array}{l}\text { Memberikan Pelayanan Konseling } \\
\text { Menggunakan fasilitas video call di } \\
\text { WhatsApp, Instagram atau Line }\end{array}$ \\
\hline
\end{tabular}

Dalam kondisi saat ini Gereja dan komunitas penginjil tidak dapat terlepas dari penggunaan media sosial digital, perubahan era digital. Penginjilan melalui media digital harus dijalankan secara baik dan teratur seperti contoh teologi siber mengatakan digital terkoneksi ke seluruh tempat dan memperluas relasi walaupun tidak secara tatap muka langsung. ${ }^{29}$ Seorang

${ }^{29}$ Mick Mordekhai Sopacoly and Izak Y.M. Lattu, "Kekristenan Dan Spiritualitas Online: Cybertheology Sebagai Sumbangsih Berteologi Di Indonesia," GEMA TEOLOGIKA: Jurnal Teologi Kontekstual dan Filsafat Keilahian 5, no. 2 (2020): 137. 
penginjil harus siap memberikan layanan dan berinteraksi di media sosial melalui layanan doa dan memberikan kesaksian akan kebaikan Tuhan .

\section{KESIMPULAN}

Pandemi covid-19 memaksa gereja melakukan perubahan strategi dalam melakukan penginjilan dan pemuridan, karena itu perlu adanya revitalisasi penginjilan dengan menerapkan pola-pola baru. Dalam konteks inilah teologi misi juga turut berubah mengikuti bentuk pergeseran dari sisi tradisional ke arah sisi cerdas dalam era digital yang baru. Perkembangan teknologi turut mempengaruhi gereja di dalam melaksanakan revitalisasi penginjilan dan pemuridan sebagai bentuk implementasi dari Amanat Agung. Beberapa strategi dalam mengkomunikasikan pesan Injil dapat dilakukan guna menggiatkan pelayanan penginjilan yang efisien dan efektif, serta aman di masa pandemi covid-19 melalui metode media digital antara lain melalui khotbah live streaming, rekaman video, Facebook, Instagram, Zoom dan tatap muka dengan tetap memperhatikan protokol kesehatan. Selain itu, dengan media digital gereja mampu melayani jemaat dengan tidak terbatas ruang dan waktu serta memberikan peluang kepada gereja untuk melakukan penjangkauan jiwa di mana pun mereka berada.

\section{KEPUSTAKAAN}

Al, John Ruck et. Jemaat Misioner. Jakarta: Yayasan Komunikasi Bina Kasih, 2011.

Camerling, Yosua Feliciano, Mershy Ch. Lauled, and Sarah Citra Eunike. "GEREJA BERMISI MELALUI MEDIA DIGITAL DI ERA REVOLUSI INDUSTRI 4.0." VISIO DEI: JURNAL TEOLOGI KRISTEN 2, no. 1 (June 2020): 1-22.

Center, Indonesia Survey. Laporan Survei Internet APJII 2019 - 2020 (Q2), 2020.

COVID-19, Satuan Tugas Penanganan. "Apa Yang Dimaksud Dengan Pandemi?"

David J. Bosch. Transformasi Misi Kristen. Jakarta: BPK Guniung Mulia, 2016.

I, Stuart C Bate O M. "Method in Contextual Missiology 2 . A Method for Reflection as We Walk the Spiritual Journey : Some Presuppositions," no. 1962 (1998): 1-35.

KemenKes_RI. "Tata Laksana.” KKBI Daring (2020). 
Kurlberg, Jonas. "Doing God in Digital Culture: How Digitality Is Shaping Theology." Cursor_Zeitschrift für explorative Theologie (2020).

. "Introduction: Missio Dei in a Digital Age." In Missio Dei in a Digital Age, edited by Jonas Kurlberg and Peter M. Phillips. London: SCM Press, 2020.

Novira, Nina, Rudi Iskandar, and Raehanul Bahraen. "Persepsi Masyarakat Akan Pentingnya Social Distancing Dalam Penanganan Wabah Covid-19 Di Indonesia." Jurnal Kependudukan Indonesia 2902 (2020): 27.

Novita. "Pemuridan: Jalan Menuju Kedewasaan Penuh Dalam Kristus." In-Christ.

Rey, Kevin Tonny. "Konstruksi Teologi Dalam Konteks Reposisi Pemikiran Warga Gereja." EPIGRAPHE: Jurnal Teologi dan Pelayanan Kristiani 2, no. 1 (2018).

Rumbay, Christar Arstilo. "Christology in Digital Era: A SocioSystematic Theology Contribution to the Sustainable Smart Society." PASCA : Jurnal Teologi dan Pendidikan Agama Kristen 16, no. 1 (2020): 15-23.

Saputra, Hermawan, and Nadilah Salma. "Dampak PSBB Dan PSBB Transisi Di DKI Jakarta Dalam Pengendalian COVID-19." Media Kesehatan Masyarakat Indonesia 16, no. 3 (2020): 282292.

Sarwono, Jonathan. Metode Penelitian Kuantitatif Dan Kualitiatif. Yogyakarta: Graha Ilmu, 2006.

Sopacoly, Mick Mordekhai, and Izak Y.M. Lattu. "Kekristenan Dan Spiritualitas Online: Cybertheology Sebagai Sumbangsih Berteologi Di Indonesia." GEMA TEOLOGIKA: Jurnal Teologi Kontekstual dan Filsafat Keilahian 5, no. 2 (2020): 137.

Widjaja, Fransiskus Irwan. Misiologi Antara Teori, Fakta Dan Pengalaman. 1st ed. Batam: Andi Offset Yogyakarta, 2018.

Widjaja, Fransiskus Irwan, Daniel Ginting, and Sabar Manahan Hutagalung. "Teologi Misi Sebagai Teologi Amanat Agung" 1, no. 1 (2019): 17-24.

Widjaja, Fransiskus Irwan, Fredy Simanjuntak, and Noh Ibrahim Boiliu. "Repositioning Mission in Postmodern Culture." In 
Proceedings of the 1st International Conference on Education, Society, Economy, Humanity and Environment (ICESHE 2019). Paris, France: Atlantis Press, 2020. https://www.atlantispress.com/article/125936174.

Widodo, Yohanes. "Media Digital Dan Agama Di Masa Pandemi." Media Indonesia.

Wijaya, Hengki. Analisis Data Kualitatif Ilmu Pendidikan Teologi. Populasi Dan Sampel. Makassar: Sekolah Tinggi Theologia Jaffray, 2018.

"Kekristenan Di Indonesia." Wikipedia.

"Revitalisasi." Wikipedia. 